\title{
Nitrogen balance of a temperate eelgrass Zostera marina bed
}

\author{
N. Risgaard-Petersen ${ }^{1,2, *}$, T. Dalsgaard ${ }^{1}$, S. Rysgaard ${ }^{1}$, P. B. Christensen ${ }^{1}$, J. Borum ${ }^{3}$, \\ K. McGlathery ${ }^{4}$, L. P. Nielsen ${ }^{2}$
}

${ }^{1}$ National Environmental Research Institution, Department of Lake \& Estuarine Ecology, Vejlsøvej 25, DK-8600 Silkeborg, Denmark

${ }^{2}$ Institute of Biological Science, Department of Microbial Ecology, University of Aarhus, Ny Munkegade, Bldg 540. DK-8000 Århus C, Denmark

${ }^{3}$ Freshwater Biological Laboratory, University of Copenhagen, Helsingorsgade 51, DK-3400 Hillerod, Denmark

${ }^{4}$ Department of Environmental Sciences, University of Virginia, Charlottesville, Virginia 22903, USA

\begin{abstract}
The nitrogen balance of a shallow water eelgrass Zostera marina L bed was assessed in April and August 1995 by quantifying pools of nitrogen in plants and sediment and by measuring rates of nitrogen inputs and losses in vegetated and bare sediments. The total pool of nitrogen in the vegetated sediment doubled from April to August. The exchange of inorganic nitrogen between water column and sediment was measured in benthic flux chambers, and showed that vegetated sediment was a sink for water column nitrogen in both April and August. Net nitrogen fluxes of $\mathrm{NO}_{3}{ }^{-}$and $\mathrm{NH}_{4}{ }^{+}$were controlled mainly by light dependent nitrogen uptake in eelgrass leaves, which accounted for $60 \%$ of the estimated nitrogen requirements for plant growth. Nitrogen fixation was stimulated by eelgrass photosynthesis, but contributed less than $4 \%$ to total nitrogen input. The nitrogen mass balance suggested a large import of particulate nitrogen in addition to net uptake of inorganic nitrogen. Nitrogen was lost from the vegetated sediment mainly via export of leaves. Rates of denitrification measured with in situ techniques were low compared to the activity in bare sediments of similar areas. Increased denitrification was found in the eelgrass rhizosphere in April, but the overall denitrification activity within the bed barely balanced nitrogen fixation. The study shows that eelgrass vegetated sediments may influence the nitrogen cycling of shallow waters substantially by incorporating large pools of nitrogen into slowly degradable material, making nitrogen at least temporally unavailable to phytoplankton and ephemeral macroalgae. The results also suggest that neither nitrogen fixation nor denitrification plays a major role in the nitrogen dynamics of eelgrass beds.
\end{abstract}

KEY WORDS: DIN flux $\cdot$ Plant $\mathrm{N}$ uptake $\cdot$ Plant $\mathrm{N}$ loss $\cdot$ Denitrification $\mathrm{N}_{2}$ fixation

\section{INTRODUCTION}

Eelgrass Zostera marina (L.) forms extensive and highly productive beds in sheltered shallow estuaries in Northern Hemisphere coastal areas (den Hartog 1970). During the past 3 to 5 decades increased anthropogenic nitrogen loading (Nixon 1995) has significantly reduced the abundance and depth penetration of the plants (Duarte 1995, Borum 1996). It is likely that eelgrass biomass and abundance will increase if nitro-

·E-mail: nils.risgaard-petersen@biology.aau.dk gen loading is reduced, although such recolonization of former eelgrass vegetated areas is a slow process (Duarte 1995).

The presence of eelgrass influences nitrogen availability in estuaries. The beds are considered to be nitrogen sinks, and both the exchange of nitrogen between the water column and the sediment and the processes of nitrification and denitrification are thought to be strongly enhanced by the presence of the plants (Caffrey \& Kemp 1990, Hemminga et al. 1991, Flindt 1994).

Eelgrass beds generally exhibit high annual primary production rates, and significant amounts of nitrogen 
are therefore required to support this growth. Some of this requirement is met by internal recycling (Borum et al. 1989), but up to $80 \%$ is taken up from the sediment and water column (Hemminga et al. 1991, and references therein, Pedersen \& Borum 1993). Approximately $50 \%$ of the annual nitrogen uptake is drawn from the water column (Hemminga et al. 1991, Pedersen \& Borum 1993) while the rest is taken from the sediment. Total annual nitrogen incorporation may exceed 2 mol nitrogen $\mathrm{m}^{-2}$ (Pedersen \& Borum 1993), and a substantial fraction of this nitrogen is accumulated within eelgrass beds during the growth season. Conversely assimilated nitrogen is exported to adjacent areas via loss of leaves (Bach et al. 1986). Eelgrass tissues decompose relatively slowly (Harrison 1989, Buchsbaum et al. 1991, Enriquez et al. 1993) and assimilated nitrogen therefore is retained within the tissue for long periods. The integrated effect of eelgrass nitrogen incorporation is that nitrogen is temporarily immobilized and made unavailable for other autotrophs.

Eelgrass beds also are efficient sinks for particulate nitrogen, because current velocity is decreased in the eelgrass canopy (Hemminga et al. 1991), which favors sedimentation and accumulation of suspended matter (Kenworthy et al. 1982). This import of nitrogen to the eelgrass bed from accumulated organic matter supplements sediment pools of nitrogen available for plant uptake.

Nitrogen fixation in seagrass vegetated sediments is often enhanced when compared to that in bare sediments (O'Donohue et al. 1991, Moriarty \& O'Donohue 1993, Welsh et al. 1996, McGlathery et al. 1998), and it has been suggested that the activity of nitrogen fixating bacteria is associated with the release of photosynthetic exudates via the roots (O'Donohue et al. 1991, Welsh et al. 1997, McGlathery et al. 1998). This nitrogen may be a supplementary nitrogen source for plant uptake, and for some nitrogen limited seagrass ecosystems up to $50 \%$ of the nitrogen requirements for plant growth is supported by bacterial nitrogen fixation (O'Donohue et al. 1991)

Rooted macrophytes may also promote loss of nitrogen through increased coupled nitrification-denitrification. The plants transport $\mathrm{O}_{2}$ from leaves to roots via an air-lacuna system, and the $\mathrm{O}_{2}$ can then diffuse from the roots into the sediment (Armstrong 1967, SandJensen 1982, Christensen et al. 1994). Here it can be used for $\mathrm{NO}_{3}{ }^{-}$production by nitrifying bacteria. This $\mathrm{NO}_{3}{ }^{-}$can thereafter undergo denitrification in the anoxic sediment surrounding the roots (Christensen \& Sørensen 1986, Caffrey \& Kemp 1992, RisgaardPetersen \& Jensen 1997). Indirect experimental results, based on nitrogen mass balance studies of laboratory incubated sediment with Zostera marina plants (Flindt
1994), and measurements of the potential for nitrification and denitrification (Caffery \& Kemp 1990), further indicate that such a mechanism may increase nitrogen loss from eelgrass vegetated sediments. However, at present no direct evidence for elevated coupled nitrification-denitrification activity in the eelgrass rhizosphere is published. The presence of eelgrass may also increase the sediment organic content (Hemminga et al. 1991) and reduce ammonium avallability, making rhizosphere conditions for coupled nitrification-denitrification less favorable.

Most studies on nitrogen dynamics in eelgrass beds have focused on individual processes responsible for the uptake and loss of nitrogen (for a thorough review see Hemminga et al. 1991). It is clear, however, that a better understanding of the nitrogen dynamics in these systems requires integrated studies of the plants in the complex ecosystem in which they function. In the present study, we measured processes of loss and gain of nitrogen in a temperate Zostera marina bed during periods of the most active growth season. The aim of the study was to identify the most important processes responsible for the exchange of nitrogen between the vegetated sediment and the water column and thus evaluate the role of the bed as a nitrogen sink.

\section{MATERIALS AND METHODS}

Study site. Nitrogen transformations were studied in situ during field campaigns in April and August 1995 in an eelgrass Zostera marina (L.) bed located in the eastern part of Løgstør Bredning $\left(56.58^{\circ} \mathrm{N}, 9.16^{\circ} \mathrm{E}\right)$, Limfjorden, Denmark. April represents the start of the most active growth season, with high specific plant growth rates, but relatively low biomass, and August represents maximum area-based production due to high plant biomass (Sand-Jensen 1975). Water depth within the bed was 0.6 to $1.2 \mathrm{~m}$. The eelgrass bed was patchy and covered $-70 \%$ of the sea floor.

In situ measurements of fluxes. Fluxes of $\mathrm{O}_{2}, \mathrm{NO}_{3}^{-}$ and $\mathrm{NH}_{4}{ }^{+}$between the water column and the sediment-eelgrass community were measured in situ during the day and at night in benthic flux chambers (Fig. 1). The chambers (height: $50 \mathrm{~cm}_{i}$ surface area: $30 \times 30 \mathrm{~cm}$ ) were made of transparent Plexiglas, and equipped with a transparent lid, kept in place by nylon screws. A rotor, consisting of 4 rods $19.5 \times 1.3 \mathrm{~cm}$, each inserted perpendicular to the next into a $5.5 \mathrm{~cm}$ diameter disc), was mounted on the lid of the chambers. This device contained magnets coupled to an external mag. net driven by a stepper motor. During incubation the rotating speed of the rotor was set to $15 \mathrm{rpm}$. A detailed description of the in situ incubation chamber is given by Glud et al. (1995). 
The chambers ( $n=3$ ) were placed within the eelgrass bed at least $6 \mathrm{~h}$ prior to incubation, and left open until incubation was initiated. The chambers were pushed approximately $20 \mathrm{~cm}$ into the sediment, leaving $30 \mathrm{~cm}$ of water column. In August, when eelgrass leaves were much longer than the height of the chamber, a nylon net (mesh size: $1 \times 1 \mathrm{~cm}$; line thickness: $0.3 \mathrm{~mm}$ ) was mounted inside the chambers to prevent the leaves from becoming entangled in the rotor.

During the 2 to $5 \mathrm{~h}$ of incubation, 5 water samples of $100 \mathrm{ml}$ were collected at regular time intervals. The samples were collected with $50 \mathrm{ml}$ plastic syringes through Tygon tubes mounted on the chambers, and the extracted water was replaced by an equal volume of ambient sea water.

Samples for $\mathrm{O}_{2}$ determinations were transferred to glass vials (Exetainer, Labco, High Wycombe, UK) and Winkler reagents were added immediately. Samples for $\mathrm{NO}_{3}{ }^{-}$and $\mathrm{NH}_{4}{ }^{+}$determinations were filtered through Whatman GF/C glass fiber filters, transferred to plastic vials, and then immediately frozen on dry ice $\left(-57^{\circ} \mathrm{C}\right)$.

In order to distinguish between plant and sediment effects on fluxes, measurements were also performed on bare sediment sampled between the plants. The upper $10 \mathrm{~cm}$ of the sediment was sampled by hand in core tubes (inner diameter [i.d.]: $5 \mathrm{~cm}$; length: $30 \mathrm{~cm}$; $n=5$ ), which then were placed on the sea floor a few meters away from the benthic flux chambers. Constant movement of the water column above the cores was provided by rotating Teflon-coated magnets mounted inside the core tubes approximately $5 \mathrm{~cm}$ above the sediment surface. The magnets received momentum from an external rotating magnet driven by a waterproof stepper motor. This motor was mounted on a stand, to which the core tubes were fixed. The core tubes were left open $\sim 2 \mathrm{~h}$ and were then sealed with transparent lids when incubation was initiated.

After 2 to $6 \mathrm{~h}$ of incubation, water samples for $\mathrm{O}_{2}$, $\mathrm{NO}_{3}{ }^{-}$, and $\mathrm{NH}_{4}{ }^{+}$determinations were collected with a syringe, processed, and stored as described above. Initial samples for determinations of these species were collected from the ambient water.

In situ measurements of denitrification. Rates of surface associated denitrification in the eelgrass vegetated sediment were measured in situ during the day and night in the benthic flux chambers ( $\mathrm{n}=3$ ) A volume of $30 \mathrm{ml}$ of a $100 \mathrm{mM}^{15} \mathrm{NO}_{3}{ }^{-}$stock solution $\left({ }^{15} \mathrm{~N}\right.$ abundance: 99 atom \% ) was added to the water column of the chambers after they were sealed with transparent lids.

Five times during the 2 to $6 \mathrm{~h}$ incubation, water samples for ${ }^{29} \mathrm{~N}_{2},{ }^{30} \mathrm{~N}_{2}, \mathrm{O}_{2}$, and ${ }^{15} \mathrm{NO}_{3}{ }^{-}$enrichment determinations were collected from the water column of the chambers. Samples for ${ }^{15} \mathrm{NO}_{3}{ }^{-}$determination were pro-

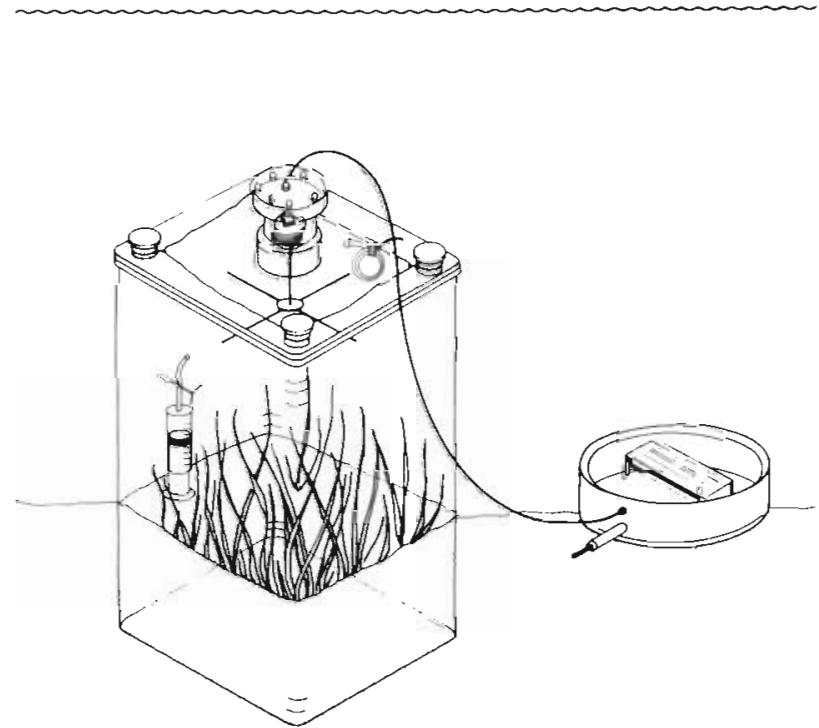

Fig. 1. Benthic flux chamber with rotor and external battery

cessed and stored as described above, and samples for ${ }^{29} \mathrm{~N}_{2}$ and ${ }^{30} \mathrm{~N}_{2}$ determinations were transferred to glass vials (Exetainer) and preserved with $250 \mu \mathrm{l} 7 \mathrm{M} \mathrm{ZnCl}_{2}$.

${ }^{29} \mathrm{~N}_{2}$ and ${ }^{30} \mathrm{~N}_{2}$ that had accumulated in the sediment pore water during the incubation were collected at the end of the experiment, because this procedure requires destructive sampling. The lids of the benthic flux chambers were carefully removed, and from each of the chambers 5 subsamples of sediment, including the lowest few cm of the water column, were collected in small core tubes (i.d.: $3.5 \mathrm{~cm}$; length: $12 \mathrm{~cm}$ ). A sample of the water column in the core for ${ }^{29} N_{2}$ and ${ }^{30} N_{2}$ determinations was taken as described above. Water and sediment in the core tubes were then gently mixed with a rod, after addition of $0.5 \mathrm{ml} 7 \mathrm{M} \mathrm{ZnCl}_{2}$. A sample of this sediment-water suspension was collected with a glass syringe, transferred to glass vials and preserved with $250 \mu l 7 \mathrm{M} \mathrm{ZnCl}_{2}$ for later analysis of ${ }^{15} \mathrm{~N}$ labeled $\mathrm{N}_{2}$ species.

Coupled nitrification-denitrification in the eelgrass rhizosphere. Coupled nitrification-denitrification in the rhizosphere was estimated with a perfusion technique that allowed us to distribute ${ }^{15} \mathrm{NH}_{4}{ }^{+}$homogeneously throughout the rhizosphere. This technique was based on a replacement of the sediment pore water with ${ }^{15} \mathrm{NH}_{4}^{+}$enriched pore water. Sediment cores (length: $15 \mathrm{~cm}$ ) containing intact plants were collected by hand in Plexiglas core tubes $(50 \mathrm{~cm}$ long and $10 \mathrm{~cm}$ in diameter), brought to the laboratory, and placed in an open tank with aerated in situ water. The core tubes were equipped with 2 vertical rows of silicon sealed holes positioned at $1 \mathrm{~cm}$ depth intervals. A $3 \mathrm{~cm}$ thick PVC bottom was inserted into the core tubes 
and fixed to the tubes with a silicon greased O-ring The PVC bottom had 5 concentric grooves $10.5 \mathrm{~cm}$ wide, $0.5 \mathrm{~cm}$ deep), each connected to a radial channel. This channel was connected to a pump by Tygon tubes. The interface between the PVC bottom and the sediment in core tubes was covered by a nylon net to prevent sediment loss during the pore water extraction procedure.

The pore water of the cores was drained with a vacuum pump and collected in glass bottles. The extracted pore water was kept anoxic by purging with $\mathrm{N}_{2}$, and ${ }^{15} \mathrm{NH}_{4}{ }^{+}\left(500 \mu \mathrm{M}, 99\right.$ atom $\left.\%{ }^{15} \mathrm{~N}\right)$ was added before the water was drawn back into the intact sediment core. Four ${ }^{15} \mathrm{NH}_{4}{ }^{+}$enriched sediment cores were incubated outdoors for about $6 \mathrm{~h}$ during the day, and 4 cores were incubated $6 \mathrm{~h}$ at night. Samples of ${ }^{29} \mathrm{~N}_{2}$ and ${ }^{30} \mathrm{~N}_{2}$ in the pore water and the water column were taken at the beginning and at the end of the incubation period. Water samples of $1 \mathrm{ml}$ were collected from the water column and at 1 to $2 \mathrm{~cm}$ depth intervals in the sediment down to a depth of $13 \mathrm{~cm}$ below the sediment surface with a syringe through the silicone sealed holes. The samples for ${ }^{15} \mathrm{~N}_{2}$ mass spectrometry analysis were transferred to $6 \mathrm{ml} \mathrm{He-purged,} \mathrm{pre-evacuated} \mathrm{glass}$ vials (Exetainer) containing $100 \mu \mathrm{l} \mathrm{M} \mathrm{ZnCl}_{2}$.

Nitrogen fixation in eelgrass vegetated sediment. Bacterial $\mathrm{N}_{2}$ fixation activity was measured by the $\mathrm{C}_{2} \mathrm{H}_{2}$ reduction method (Hardy et al. 1968) adapted to a setup similar to the one used for measuring coupled nitrification-denitrification in the rhizosphere. The pore water was drained and $\mathrm{C}_{2} \mathrm{H}_{2}(20 \%)$ was added before the pore water was drawn back into the rhizosphere as described above. Four sediment cores were incubated for about $6 \mathrm{~h}$ under in situ light conditions and 4 were incubated in the dark. Initial and final samples for $\mathrm{C}_{2} \mathrm{H}_{4}$ determination were collected from sediment pore water and the water column with a syringe, as described above. Samples of $1 \mathrm{ml}$ of water were transferred to venojects (Teromo, Europe) and preserved with 25 ul $7 \mathrm{M} \mathrm{ZnCl}_{2}$

Nitrogen pools in eelgrass and in the sediment. For determinations of plant-bound nitrogen, eelgrass leaves, roots and rhizomes were collected with a $18 \mathrm{~cm}$ i.d. steel tube forced $\sim 20 \mathrm{~cm}$ into the sediment. Six samples were taken within the bed and the plant material was washed in a $1 \mathrm{~mm}$ sieve in the field. The plants were sorted, counted and separated into leaves and root/rhizomes, and subsequently dried to constant weight at $90^{\circ} \mathrm{C}$. Subsamples of dried plant material were stored in plastic vials for later nitrogen determination.

Nitrogen bound to sediment particles was determined in cores taken from in between the eelgrass plants. The cores $(n=3)$ were collected down to a depth of $20 \mathrm{~cm}$ in Plexiglas tubes (i.d.: $4.2 \mathrm{~cm}$ ), and frozen $\left(-18^{\circ} \mathrm{C}\right)$ to keep root/rhizomes and dead particulate plant material in a fixed position. Subsequently, the cores were sliced into 1 to $4 \mathrm{~cm}$ sections with a thin saw blade. The sediment material was dried to constant weight at $90^{\circ} \mathrm{C}$ and then sieved to separate particulate organic matter (defined as particles $>1 \mathrm{~mm}$ ) from the bulk sediment. Subsamples of sediment and particulate organic material were stored in plastic vials for later nitrogen determinations.

Eelgrass nitrogen incorporation, nitrogen reclamation and nitrogen losses. Nitrogen incorporation into eelgrass tissue, internal recycling of nitrogen in the plants, plant nitrogen demand, and losses of nitrogen from the live biomass were estimated from the growth of leaves and roots/rhizomes, the tissue-specific nitrogen content of leaves and groups of roots/rhizomes of different age, and changes in above-and belowground biomass between April and August (Pedersen \& Borum 1993)

Growth of eelgrass leaves was determined by the in situ leaf marking technique (Sand-Jensen 1975). Root/ rhizome growth was estimated from the production of new leaves, since 1 new root/rhizome inter-node is produced for each new leaf (Pedersen \& Borum 1993).

Additional plants $(n=9)$ were collected and separated into leaves and groups of roots/rhizomes of different ages for analysis of the tissue-specific nitrogen contents (Borum et al. 1989). The leaves were scraped free of epiphytes by a scalpel before being dried to constant weight at $60^{\circ} \mathrm{C}$.

Analyses. Nitrate was determined using a standard method (Grasshoff et al. 1983) on a flow injection analyzer (Perstop Analytical, Environmental Wilsonville, Oregon, USA). Ammonium was analyzed colorimetrically as described by Bower \& Holm-Hansen (1980). Oxygen was determined by the Winkler titration method (Grasshoff et al. 1983) within a few hours after sampling.

Abundance of ${ }^{29} \mathrm{~N}_{2}$ and ${ }^{30} \mathrm{~N}_{2}$ in water samples and sediment-water suspensions was determined on a combined gas chromatrograph-mass spectrometer (RopoPrep-G+ in line with Tracermass, Europa Scientific, Crewe, UK) as described by Risgaard-Petersen \& Rysgaard (1995).

The ${ }^{15} \mathrm{~N}$ atom \% of $\mathrm{NO}_{3}{ }^{-}$in the ${ }^{15} \mathrm{NO}_{3}{ }^{-}$amended flux chambers was measured by mass spectrometry after biological reduction to $\mathrm{N}_{2}$ (Risgaard-Petersen et al. 1993).

Ethylene and acetylene were determined on a HP5890 gas chromatograph equipped with an FID detector and a poraplot U-type column $(10 \mathrm{~m}, 0.53 \mathrm{~mm}$, $20 \mu \mathrm{m})$.

Particulate nitrogen in plants and sediment was measured on a CN elemental analyzer (RopoPrep-CN)

Calculations. Fluxes of $\mathrm{NO}_{3}{ }^{-}, \mathrm{NH}_{4}{ }^{+}, \mathrm{O}_{2},{ }^{29} \mathrm{~N}_{2}$ and ${ }^{30} \mathrm{~N}_{2}$ were calculated from the changes in concentrations in 
the chambers with time by linear regression using all solute concentrations measured in the water overlying the sediments (benthic flux chambers, $\mathrm{n}=5$; core tubes, $\mathrm{n}=2$ ).

In situ denitrification activity in the sediment surface (i.e. denitrification of ${ }^{14} \mathrm{NO}_{3}{ }^{-}$) was estimated with the isotope pairing technique from the production rates of ${ }^{29} \mathrm{~N}_{2}$ and ${ }^{30} \mathrm{~N}_{2}$ in the ${ }^{15} \mathrm{NO}_{3}{ }^{-}$amended flux chambers (Nielsen 1992). Production rates of ${ }^{15} \mathrm{~N}_{2}$ (i.e. ${ }^{29} \mathrm{~N}_{2}$ and ${ }^{30} \mathrm{~N}_{2}$ ) were calculated as the sum of ${ }^{15} \mathrm{~N}_{2}$ fluxes from the sediment to the water column and the rate of ${ }^{15} \mathrm{~N}_{2}$ accumulation in the sediment. The denitrification activity was divided into rates of coupled nitrificationdenitrification and denitrification of $\mathrm{NO}_{3}^{-}$supplied from the water column, as described by Nielsen (1992).

Denitrification in the eelgrass rhizosphere was calculated from the production of ${ }^{29} \mathrm{~N}_{2}$ and ${ }^{30} \mathrm{~N}_{2}$ in the ${ }^{15} \mathrm{NH}_{4}{ }^{+}$amended perfusion cores, using the isotope pairing technique. Depth-specific coupled nitrification-denitrification of both ${ }^{15} \mathrm{NH}_{4}{ }^{+}$and ${ }^{14} \mathrm{NH}_{4}$ was calculated for each 1 to $2 \mathrm{~cm}$ depth interval.

Rates of $\mathrm{N}_{2}$ fixation in the eelgrass rhizosphere were calculated from the $\mathrm{C}_{2} \mathrm{H}_{4}$ production rates in the $\mathrm{C}_{2} \mathrm{H}_{2}$ amended perfusion cores using the stoichiometric relationship of $1 \mathrm{~mol} \mathrm{~N}_{2}$ fixed for every $3 \mathrm{~mol} \mathrm{C}_{2} \mathrm{H}_{2}$ reduced (O'Donohue et al. 1991).

Diurnal flux, denitrification, and $\mathrm{N}_{2}$ fixation rates were calculated from rates obtained during the day and at night. A $15 / 9 \mathrm{~h}$ light/dark diurnal cycle was used in April, and in August a 16/8 h light/dark diurnal cycle was used.

Eelgrass nitrogen incorporation, nitrogen uptake into new tissue, recycling of nitrogen from old to new plant parts, and losses of nitrogen from the leaves or the roots were estimated from the growth of the plants, age-specific nitrogen content of leaves and roots/rhizomes, and the eelgrass biomass. For further details see Pedersen \& Borum (1993).

\section{RESULTS}

\section{Physical, chemical and biological description of the sampling station}

The bottom water temperature increased from April to August due to increased irradiance (Table 1A). Bottom water $\mathrm{O}_{2}$ concentration was equivalent to atmospheric saturation in April, whereas a large reduction in $\mathrm{O}_{2}$ was observed at night in August. Nitrate and $\mathrm{NH}_{4}{ }^{+}$ concentrations were highest in April. Eelgrass production was highest in August (Table 1B). The shoot density decreased from April to August but total eelgrass biomass remained roughly the same. Probably the mild Danish winter in 1994-1995 allowed survival of a relatively large eelgrass biomass, and this might explain why the April biomass was about 2-fold higher than the values reported by Sand-Jensen (1975), whereas the August biomass was similar.

\section{Exchange of $\mathrm{O}_{2}$ and dissolved inorganic nitrogen between the water column and the sediments}

In both April and August, rates of net $\mathrm{O}_{2}$ production in the light and rates of $\mathrm{O}_{2}$ consumption in the dark were highest for the eelgrass vegetated sediment (Table 2). Over a diurnal cycle the vegetated sediment was net $\mathrm{O}_{2}$ producing, whereas the bare sediment was net $\mathrm{O}_{2}$ consuming. This shows that eelgrass and the

Table 1. (A) Bottom water temperature, light intensities as average $\pm \mathrm{SE}$ (given in parentheses) for 11:00 to 15:00 $\mathrm{h}, \mathrm{O}_{2}, \mathrm{NO}_{3}{ }^{-}$and $\mathrm{NH}_{4}{ }^{+}$concentrations during the April and August campaigns. nd: values below detection limit. (B) Eelgrass Zostera marina biomass, production and shoot density at the field site in April and August. For biomass and shoot density, SE are given in parentheses, $n=6$

\begin{tabular}{|c|c|c|c|c|c|c|c|}
\hline \multicolumn{8}{|c|}{ (A) Bottom water characteristics } \\
\hline & \multicolumn{2}{|c|}{$\begin{array}{l}\text { Temperature } \\
\qquad\left({ }^{\circ} \mathrm{C}\right)\end{array}$} & \multirow{2}{*}{$\begin{array}{c}\text { Light ( } 1 \mathrm{~mol} \\
\left.\text { photons } \mathrm{m}^{-2} \mathrm{~s}^{-1}\right) \\
\text { Day }\end{array}$} & \multicolumn{2}{|c|}{$\begin{array}{c}\mathrm{O}_{2}(\% \text { of } \\
\text { saturation) }\end{array}$} & \multirow[t]{2}{*}{$\begin{array}{l}\mathrm{NO}_{3}^{-} \\
(\mu \mathrm{M})\end{array}$} & \multirow[t]{2}{*}{$\begin{array}{l}\mathrm{NH}_{4}{ }^{+} \\
(\mu \mathrm{M})\end{array}$} \\
\hline & Day & Night & & Day & Night & & \\
\hline April & 14 & 11 & $483(35)$ & 100 & 100 & 26 & 5 \\
\hline August & 22 & 20 & $535(13)$ & 100 & 15 & 2 & nd \\
\hline \multicolumn{8}{|c|}{ (B) Eelgrass characteristics } \\
\hline & \multicolumn{2}{|c|}{$\begin{array}{l}\text { Aboveground } \\
\text { biomass } \\
\left(\mathrm{gdw} \mathrm{m}^{-2}\right)\end{array}$} & $\begin{array}{l}\text { Belowground } \\
\text { biomass } \\
\left(\mathrm{g} \mathrm{dw} \mathrm{m}^{-2}\right)\end{array}$ & \multicolumn{2}{|c|}{$\begin{array}{c}\text { Leaf } \\
\text { production } \\
\left(g d w m^{-2} d^{-1}\right)\end{array}$} & $\begin{array}{c}\text { Root/rhizome } \\
\text { production } \\
\left(g d w \mathrm{~m}^{-2} \mathrm{~d}^{-1}\right)\end{array}$ & $\begin{array}{c}\text { Shoot } \\
\text { density } \\
\text { (shoots } \mathrm{m}^{-2} \text { ) }\end{array}$ \\
\hline April & \multicolumn{2}{|c|}{$172(61)$} & $274(65)$ & \multicolumn{2}{|c|}{3.4} & 2.4 & $1500(301)$ \\
\hline August & \multicolumn{2}{|c|}{$223(75)$} & $256(124)$ & \multicolumn{2}{|c|}{7.8} & 2.0 & $962(270)$ \\
\hline
\end{tabular}


Table 2. Fluxes of $\mathrm{O}_{2}, \mathrm{NO}_{3}{ }^{-}$and $\mathrm{NH}_{4}{ }^{+}$between the water column and the eelgrass vegetated sedıment, and between the water column and bare sediment. Negative fluxes represent net uptake from the water column. Standard errors are given ın parentheses (for the vegetated sediment: $\mathrm{n}=3$; for the bare sediment: $\mathrm{n}=5$ ). nd: values below detection limit

\begin{tabular}{|c|c|c|c|c|c|c|c|c|c|c|}
\hline & & \multicolumn{3}{|c|}{$\mathrm{O}_{2}\left(\mathrm{mmol} \mathrm{O} \mathrm{m}^{-2} \mathrm{~d}^{-1}\right)$} & \multicolumn{3}{|c|}{$\mathrm{NO}_{3}^{-}\left(\mathrm{mmol} \mathrm{N} \mathrm{m}{ }^{-2} \mathrm{~d}^{-1}\right)$} & \multicolumn{3}{|c|}{$\mathrm{NH}_{4}^{+}\left(\mathrm{mmol} \mathrm{N} \mathrm{m}{ }^{-2} \mathrm{~d}^{-1}\right)$} \\
\hline & & Light & Dark & Day & Light & Dark & Day & Light & Dark & Day \\
\hline April & $\begin{array}{l}\text { Vegetated sediment } \\
\text { Bare sediment }\end{array}$ & $\begin{array}{r}304(22) \\
-3(18)\end{array}$ & $\begin{array}{r}-152(6) \\
-53(5)\end{array}$ & $\begin{array}{l}133(13) \\
-22(11)\end{array}$ & $\begin{array}{l}-12(2) \\
-2(0.3)\end{array}$ & $\begin{array}{l}-5(2) \\
-1(0.2)\end{array}$ & $\begin{array}{r}-9(2.2) \\
-1.6(0.2)\end{array}$ & $\begin{array}{l}-3(0.3) \\
-1(0.3)\end{array}$ & $\begin{array}{l}-1.5(0.2) \\
-0.6(0.2)\end{array}$ & $\begin{array}{l}-2.4(0.2) \\
-0.9(0.2)\end{array}$ \\
\hline August & $\begin{array}{l}\text { Vegetated sediment } \\
\text { Bare sediment }\end{array}$ & $\begin{array}{l}625(88) \\
-27(13)\end{array}$ & $\begin{array}{r}-290(40) \\
-97(20)\end{array}$ & $\begin{array}{l}313(58) \\
-51(11)\end{array}$ & $\begin{array}{l}-6(2) \\
-3(0.2)\end{array}$ & $\begin{array}{l}-1(0.3) \\
-1(0.1)\end{array}$ & $\begin{array}{l}-5(1) \\
-2(0.1)\end{array}$ & $\begin{array}{l}\text { nd } \\
\text { nd }\end{array}$ & $\begin{array}{l}\text { nd } \\
\text { nd }\end{array}$ & $\begin{array}{l}\text { nd } \\
\text { n.d }\end{array}$ \\
\hline
\end{tabular}

Table 3. Rates of denitrificdtion of $\mathrm{NO}_{3}{ }^{-}$taken from the water column $\left(D_{\mathrm{w}}\right)$, coupled nitrification-denitrification $\left(D_{\mathrm{n}}\right)$, and $\mathrm{N}_{2}$ fixation in the eelgrass vegetated sediment. Surface denitrification rates were measured in the benthic flux chambers. Rhizosphere associated denitrification was measured with the perfusion technique and represent the activity below $1 \mathrm{~cm}$ depth. $\mathrm{N}_{2} \mathrm{fixation}$ activity was likewise measured with the perfusion technique and represents the depth integrated activity in the 0 to $12 \mathrm{~cm}$ depth interval of the sediment. Standard errors are given in parentheses. For surface denitrification: $\mathrm{n}=3$; for rhizosphere denitrification and $\mathrm{N}_{2}$ fixation: $\mathrm{n}=4$. nd: values below detection limit

\begin{tabular}{|c|c|c|c|c|c|c|c|c|c|c|c|c|c|}
\hline & & \multicolumn{3}{|c|}{$\begin{array}{c}D_{\mathrm{w}} \text { at surface } \\
\left(\mathrm{mmol} \mathrm{N} \mathrm{m}^{-2} \mathrm{~d}^{-1}\right)\end{array}$} & \multicolumn{3}{|c|}{$\begin{array}{c}D_{\mathrm{n}} \text { at surface } \\
\left(\mathrm{mmol} \mathrm{N} \mathrm{m}^{-2} \mathrm{~d}^{-1}\right)\end{array}$} & \multicolumn{3}{|c|}{$\begin{array}{l}D_{\mathrm{n}} \text { in rhizosphere } \\
\left(\mathrm{mmol} \mathrm{N} \mathrm{m}^{-2} \mathrm{~d}^{-1}\right)\end{array}$} & \multicolumn{3}{|c|}{$\begin{array}{c}\mathrm{N}_{2} \text { fixation } \\
\left(\mathrm{mmol} \mathrm{N} \mathrm{m} \mathrm{m}^{-2} \mathrm{~d}^{-1}\right)\end{array}$} \\
\hline & & Light & Dark & Day & Light & Dark & Day & Light & Dark & Day & Light & Dark & Day \\
\hline Apri] & Vegetated sediment & $\begin{array}{c}0.14 \\
(0.01)\end{array}$ & $\begin{array}{c}0.46 \\
(0.01)\end{array}$ & $\begin{array}{c}0.26 \\
(0.01)\end{array}$ & $\begin{array}{c}0.06 \\
(0.01)\end{array}$ & $\begin{array}{c}0.04 \\
(0.01)\end{array}$ & $\begin{array}{c}0.05 \\
(0.01)\end{array}$ & $\begin{array}{l}0.14 \\
(0.1)\end{array}$ & nd & $\begin{array}{c}0.09 \\
(0.06)\end{array}$ & $\begin{array}{c}0.21 \\
(0.01)\end{array}$ & $\begin{array}{c}0.15 \\
(0.01)\end{array}$ & $\begin{array}{c}0.19 \\
(0.01)\end{array}$ \\
\hline August & Vegetated sediment & $\begin{array}{c}0.1 \\
(0.01)\end{array}$ & 0.05 & $\begin{array}{c}0.08 \\
(0.01)\end{array}$ & nd & nd & $n d$ & nd & nd & nd & $\begin{array}{c}0.5 \\
(0.02)\end{array}$ & $\begin{array}{c}0.3 \\
(0.03)\end{array}$ & $\begin{array}{c}0.43 \\
(0.02)\end{array}$ \\
\hline
\end{tabular}

associated epiphytes were the dominant benthic primary producers. The rate of diurnal $\mathrm{O}_{2}$ net production for the vegetated sediment increased by a factor of 2.5 from April to August. For the unvegetated sediment the rate of diurnal net $\mathrm{O}_{2}$ consumption more than doubled during this period.

There was a net uptake of both $\mathrm{NH}_{4}{ }^{+}$and $\mathrm{NO}_{3}{ }^{-}$from the water column by the unvegetated and vegetated sediments in April (Table 2), and more than $70 \%$ of this net uptake of dissolved inorganic nitrogen (DIN) was based on $\mathrm{NO}_{3}{ }^{-}$. In August, only $\mathrm{NO}_{3}$ was taken up from the water column, the $\mathrm{NH}_{4}{ }^{+}$flux was not detectable due to low $\mathrm{NH}_{4}{ }^{+}$concentrations (Table 1). Flux rates of DIN were always inghest in the light and were about 5-fold (April) or 2-fold (August) higher for the vegetated than for the unvegetated sediment. This difference indicates that the plants and their epiphytes were responsible for about $78 \%$ of the DIN exchange in April (corresponding to $8.9 \pm 2.5 \mathrm{mmol}$ nitrogen $\mathrm{m}^{-2}$ $\mathrm{d}^{-1}$ ). In August $\sim 60 \%$ of the DIN exchange could be attributed to the plants $\left(3 \pm 1.3 \mathrm{mmol}\right.$ nitrogen $\left.\mathrm{m}^{-2} \mathrm{~d}^{-1}\right)$. DIN flux rates integrated over a full diurnal cycle decreased from April to August for the sedimenteelgrass community, probably due to a decrease of $\mathrm{NO}_{3}{ }^{-}$and $\mathrm{NH}_{4}{ }^{+}$concentrations in the water column (Table 1).

\section{Denitrification}

Surface denitrification rates were highest in April (Table 3), coinciding with highest $\mathrm{NO}_{3}{ }^{-}$concentrations in the water column (Table 1). During this month the activity was based primarily on $\mathrm{NO}_{3}$ diffusing from the water column, while $\mathrm{NO}_{3}^{-}$produced by nitrification within the sediment was less important. In August denitrification was only based on $\mathrm{NO}_{3}{ }^{-}$supplied from the water column.

Only in April did we find indications for coupled nitrification-denitrification in the rhizosphere of eelgrass during the daytime. Maximum activity of coupled nitrification-denitrification in this month was found at 0.5 to $4 \mathrm{~cm}$ depth (Fig. 2), and the activity below $0.5 \mathrm{~cm}$ depth was most likely associated with the root system of eelgrass. Depth integrated, root associated coupled nitrification-denitrification activity was about $60 \%$ of the diurnal coupled nitrification-denitrification activity and approximately $25 \%$ of the total denitrification activity for the vegetated sediment (Table 3). Large spatial variation between individual cores was observed (Fig. 2), suggesting that the coupled nitrification-denitrification activity was restricted to unevenly distributed micro sites or that the root biomass was variable. 


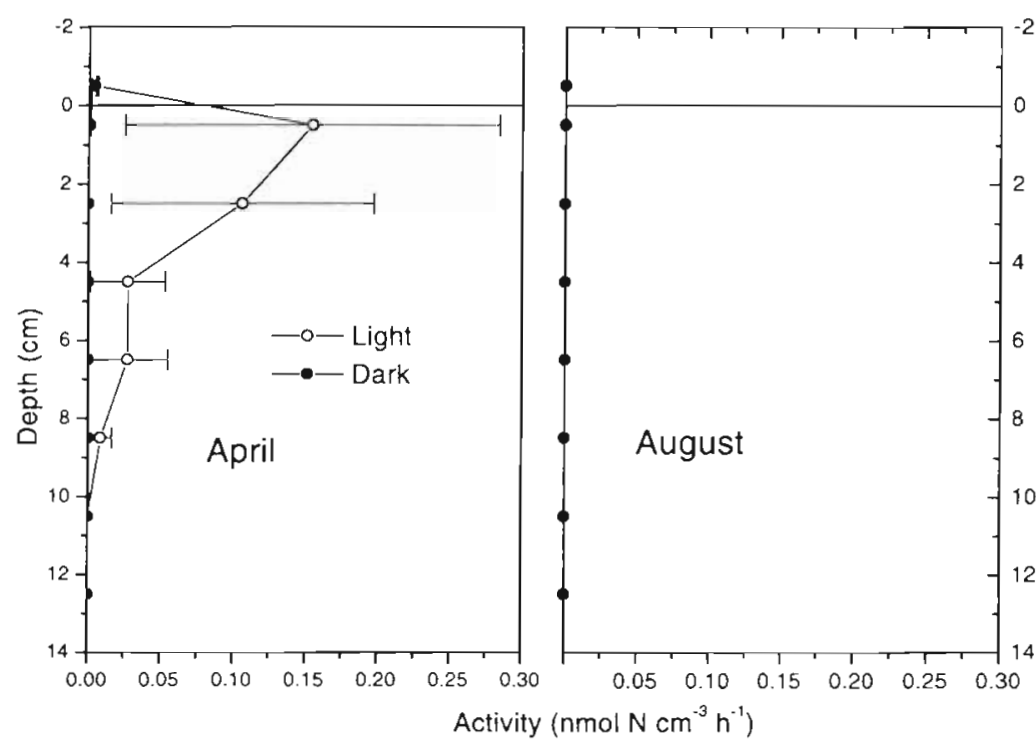

Fig. 2. Depth distribution of coupled nitrification-denitrification activity as measured by the ${ }^{15} \mathrm{NH}_{4}{ }^{+}$perfusion technique

\section{Nitrogen pools in the eelgrass bed}

The pool of plant-bound nitrogen was similar in April and August (Table 5), suggesting steady state conditions between plant nitrogen uptake and loss of plant-bound nitrogen from the biomass of eelgrass. The sediment nitrogen pool in the eelgrass vegetated sediment, however, more than doubled between April and August. Nitrogen bound to dead organic matter was $12.5 \%$ of total sediment nitrogen in April and $5.1 \%$ in August. The total nitrogen pool of the meadow, that is plant-bound nitrogen and sedimentbound nitrogen, increased significantly between April and August. The average daily nitrogen accumulation rate during this $110 \mathrm{~d}$ period was $20.6 \mathrm{mmol}$ nitrogen $\mathrm{m}^{-2} \mathrm{~d}^{-1}$.

\section{Nitrogen fixation}

In contrast to coupled nitrification-denitrification, bacterial $\mathrm{N}_{2}$ fixation was present in the eelgrass vegetated sediment both in April and August, and the activity was always highest in the light (Table 3 ). The latter may suggest a coupling between eelgrass photosynthesis and bacterial $\mathrm{N}_{2}$ fixation. Maximum rates of $\mathrm{N}_{2}$ fixation were observed in August in light incubations, when the temperature of the water column and $\mathrm{O}_{2}$ production of eelgrass were highest (Tables 1 \& 2). The $\mathrm{N}_{2}$ fixation activity almost balanced the nitrogen loss from the sediment caused by denitrification.

\section{Plant mediated uptake and loss of nitrogen}

The rate of nitrogen incorporation into the eelgrass biomass was highest in August (Table 4) when areabased production was highest. In both April and August, recycling of nitrogen from older to younger plant parts could satisfy less than $20 \%$ of the total nitrogen demand, and the sediment and the water column were consequently the main nitrogen source for the plants. During both field campaigns, nitrogen incorporation into leaves exceeded root nitrogen incorporation. Nitrogen was lost from the eelgrass biomass with a rate close to the nitrogen uptake rate (Table 4). About $78 \%$ of the nitrogen lost from the live eelgrass biomass was lost as leaf-bound nitrogen, while the remainder was lost directly to the sediment as dead roots and rhizomes.

\section{DISCUSSION}

\section{Plant mediated uptake and loss of nitrogen}

The average nitrogen incorporation rate of the plants for the April and August periods (Table 4) approached that for phytoplankton at Løgstør Bredning $(16$ mmol $\mathrm{N}$ $\mathrm{m}^{-2} \mathrm{~d}^{-1}$; estimated from primary production, data supplied by the County of Viborg, Denmark). The nitrogen was mainly taken up from the external sources, since nitrogen recycling from old to young plant parts was less important. The partition between internal and external sources agrees well with data of Pedersen \& Borum (1993).

Table 4. Zostera marina. Nitrogen incorporation, recycling, demand and losses of nitrogen for the eelgrass plants in April and August

\begin{tabular}{|c|c|c|c|c|c|}
\hline & & $\begin{array}{l}\text { Nincorp- } \\
\text { oration }\end{array}$ & $\begin{array}{l}\text { N recy- } \\
\text { cling }\end{array}$ & $\begin{array}{l}\text { N de- } \\
\text { mand }\end{array}$ & $N$ loss \\
\hline \multirow[t]{3}{*}{ April } & Roots & 2.6 & 0.8 & 1.8 & \\
\hline & Leaves & 63 & 0.5 & 5.8 & \\
\hline & Total & 8.6 & 1.3 & 7.3 & \\
\hline \multirow[t]{3}{*}{ August } & Roots & 1.9 & 0.6 & 1.3 & \\
\hline & Leaves & 12 & 2.1 & 9.9 & \\
\hline & Total & 13.9 & 2.7 & 11.2 & \\
\hline Average & Roots & 2.2 & 0.7 & 1.6 & 2.1 \\
\hline (Apr and & Leaves & 9.1 & 1.3 & 7.8 & 7.7 \\
\hline Aug) & Total & 11.3 & 2.0 & 9.4 & 9.8 \\
\hline
\end{tabular}




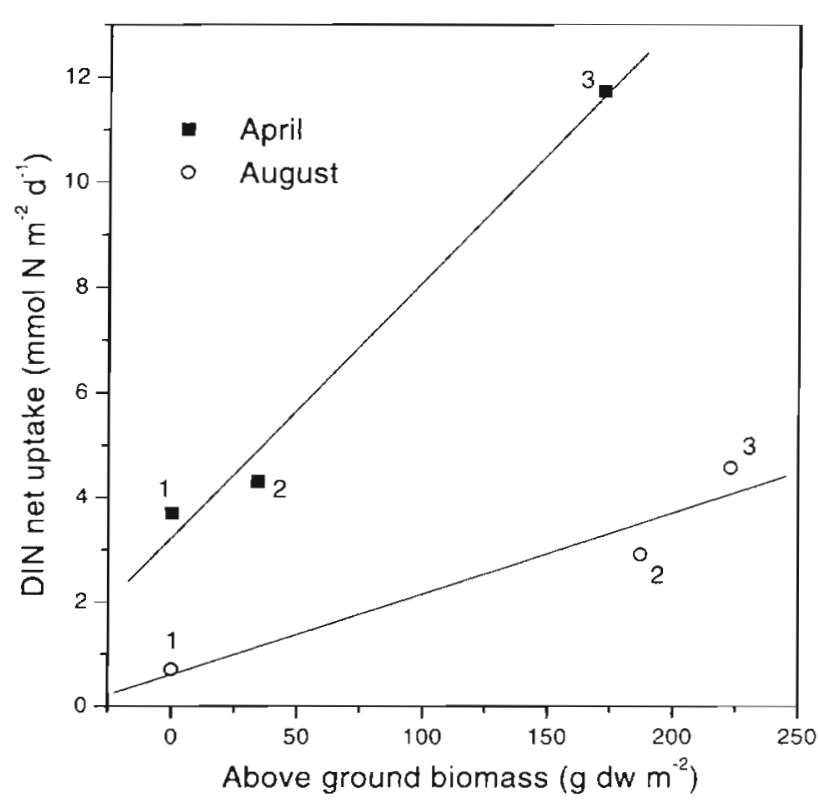

Fig. 3. DIN net uptake rates versus aboveground biomass in April and August. Data from sediments with microalgae communities (1) were supplied by E. Kristensen (pers. comm.) and generated with benthic chambers similar to those used in the present study. Data from eelgrass vegetated sediment with low aboveground biomass (2) are from Hansen et al. (unpubl.), and data from the station with high aboveground biomass (3) are from this study

Table 5. Nitrogen bound to Zostera marina leaves and roots and to different sediment compounds in April and August

\begin{tabular}{|lcccccc|}
\hline & $\begin{array}{c}\text { Eelgrass-bound } \mathrm{N} \\
\left(\mathrm{mmol} \mathrm{N} \mathrm{m} \mathrm{N}^{-2}\right) \\
\text { Leaves Roots }\end{array}$ & $\mathrm{NH}_{4}^{+}$ & $\begin{array}{c}\text { Sediment-bound N } \\
\left(\text { mmol } \mathrm{N} \mathrm{m}^{-2}\right) \\
\text { Particles Particles } \\
>1 \mathrm{~mm}\end{array}$ & $\begin{array}{c}\text { Total } \\
(\mathrm{mmol}\end{array}$ \\
$\left.\mathrm{m}^{-2}\right)$ \\
April & 316 & 294 & 25 & 184 & 1287 & 2106 \\
August & 330 & 236 & 31 & 194 & 3586 & 4377 \\
\hline
\end{tabular}

The nitrogen flux data for the vegetated and the unvegetated sediment (Table 2) and data for plant nitrogen demand (Table 4) indicate that the water column was the main nitrogen source for the plants in April. In August, when concentrations of $\mathrm{NO}_{3}^{-}$and $\mathrm{NH}_{4}{ }^{+}$in the water column were low, the plants mainly extracted their nitrogen from pools of remineralized nitrogen in the sediment. Pedersen \& Borum (1993) also showed that root uptake of nitrogen was most important during periods when $\mathrm{NO}_{3}{ }^{-}$and $\mathrm{NH}_{4}{ }^{+}$in the water column were depleted. With increasing nutrient concentration in the water column, these authors showed that leaf uptake would exceed root uptake.

The exchange of $\mathrm{NO}_{3}{ }^{-}$and $\mathrm{NH}_{4}{ }^{+}$between the water column and the vegetated sediment was mainly controlled by light dependent plant nitrogen uptake
(Table 2), which agrees with previous data reported for Zostera noltii vegetated sediments (Rysgaard et al. 1996). There was a positive correlation between aboveground eelgrass biomass and the diurnal DIN flux rate (Fig. 3), as indicated by parallel flux measurements by E. Kristensen (pers. comm.) and Hansen et al. (unpubl.). This correlation suggests that eelgrass vegetated sediments are more significant sinks for dissolved $\mathrm{NO}_{3}{ }^{-}$and $\mathrm{NH}_{4}{ }^{+}$than sediments with microalgae communities, which may result from the greater area of the eelgrass leaves exposed for nutrient uptake. However, more data points would indeed have been desirable to consolidate further this proposed relation between aboveground biomass and DIN flux.

Despite significant net uptake of $\mathrm{NO}_{3}{ }^{-}$and $\mathrm{NH}_{4}{ }^{+}$in both April and August, there was no net accumulation of nitrogen in the live eelgrass biomass (Table 5). A steady state between uptake and loss of nitrogen by the plants was therefore achieved. The turnover time of nitrogen in the live eelgrass biomass was approximately $60 \mathrm{~d}$, as estimated from nitrogen uptake rates (Table 4) and the nitrogen content of the biomass (Table 5). This nitrogen turnover is much slower than that found for planktonic algae $k<1$, Paasche \& Kristiansen 1982, Lomstein et al. 1998).

The loss of nitrogen from the live eelgrass biomass was probably the consequence of shedding of old leaves and senescence of roots/rhizomes, because both grazing (Nienhuis \& Groenendijk 1986) and leaching of nitrogen from old attached leaves or roots/rhizomes are unimportant sinks for eelgrass nitrogen (Borum et al. 1989, Pedersen \& Borum 1992). Most of the nitrogen $(-78 \%)$ was lost as leaves (Table 4$)$ and potentially subjected to export from the eelgrass bed (Bach et al. 1986), thus representing a true nitrogen loss from the eelgrass vegetated sediment. The remaining root/ rhizome-bound nitrogen that was lost directly to the sediment could be retained and eventually recycled within the bed, since the loss of mineralized nitrogen via coupled nitrification-denitrification, as indicated below, was insignificant.

\section{Nitrogen fixation}

Fixation of $\mathrm{N}_{2}$ was of no particular importance for eelgrass nitrogen uptake. Of the daily nitrogen demand of the plants (Table 4), bacterial $\mathrm{N}_{2}$ fixation could satisfy less than $3 \%$ in April and less than $4 \%$ in August. In contrast, O'Donohue et al. (1991) found that the process could supply up to half the nitrogen demand of Zostera capricorni plants, and Welsh et al. (1996) found that $\mathrm{N}_{2}$ fixation could supply about $12 \%$ of the annual nitrogen demand of $Z$. noltii plants. The 
insignificant importance of $\mathrm{N}_{2}$ fixation for the plants in this study was probably due to high nitrogen availability in the water column and the sediment (Tables 1 \& 5).

Our data may indicate a direct coupling of $\mathrm{N}_{2}$ fixation to eelgrass production and photosynthesis (Tables $2 \& 3$ ), which, as suggested by O'Donohue et al. (1991), may come from a supply of photosynthetically derived organic carbon via the root system to heterotrophic $\mathrm{N}_{2}$ fixation. Data given by McGlathery et al. (1998), who found good correlation between the spatial variation in root biomass and $\mathrm{N}_{2}$ fixation activity, and maximum activity in the summer months when eelgrass production was highest, is consistent with this hypothesis. Other studies have also reported highest $\mathrm{N}_{2}$ fixation activity in the summer for Zostera capriconi (O'Donohue et al. 1991) and for $Z$. noltii vegetated sediments (Welsh et al. 1996).

\section{Denitrification}

It has been suggested that denitrification activity is enhanced in eelgrass vegetated sediments compared to the activity of unvegetated sediments (Flindt 1994), because the plants stimulate coupled nitrificationdenitrification by $\mathrm{O}_{2}$ excretion via the root system. This suggestion was based on mass balance studies of laboratory incubated sediment with eelgrass plants (Flindt 1994) and measurements of the potential nitrificationdenitrification activity (Caffrey \& Kemp 1990), but the hypothesis has not been verified by direct measurements.

In the present study, where direct techniques were applied, denitrification was mainly based on water column $\mathrm{NO}_{3}^{-}$(Table 3). Christensen et al. (1990) estimated the rate of denitrification of water column $\mathrm{NO}_{3}{ }^{-}$ $\left(D_{w}\right)$ for unvegetated sediments from the following equation:

$$
D_{w}=F_{\mathrm{O}_{2}} \times 0.8 \times\left[\sqrt{\left(1+0.82 \times \frac{C_{\mathrm{NO}_{3}}}{C_{\mathrm{O}_{2}}} \times \frac{1}{0.8}\right)}-1\right]
$$

where $\mathrm{F}_{\mathrm{O}_{2}}$ is the sediment $\mathrm{O}_{2}$ consumption rate and $\mathrm{C}_{\mathrm{O}_{2}}$ and $\mathrm{C}_{\mathrm{NO}_{3}}$ are the $\mathrm{O}_{2}$ and $\mathrm{NO}_{3}$ - concentrations, respectively. The model assumes that denitrification is the only significant $\mathrm{NO}_{3}{ }^{-}$reducing process. Using this model to estimate denitrification activity for a sediment with $\mathrm{O}_{2}$ consumption and water column concentrations of $\mathrm{O}_{2}$ and $\mathrm{NO}_{3}{ }^{-}$similar to the sediment investigated in this study (Tables $1 \& 2$, using the $\mathrm{O}_{2}$ consumption measured on the unvegetated sediment), we found that nitrogen loss via denitrification of water column $\mathrm{NO}_{3}{ }^{-}$was much lower for the vegetated sediment than the activity expected for an equivalent bare sediment. Modeled activities were $1.5 \mathrm{mmol}$ nitrogen $\mathrm{m}^{-2} \mathrm{~d}^{-1}$ in
April and $0.4 \mathrm{mmol}$ nitrogen $\mathrm{m}^{-2} \mathrm{~d}^{-1}$ in August, which are more than 3 times the actual measured rates.

Surface and rhizosphere associated coupled nitrification-denitrification was only measurable in April. The finding that coupled nitrification-denitrification was mainly associated with the rhizosphere when the plants were photosynthetically active supports the hypothesis that eelgrass can stimulate nitrogen removal via $\mathrm{O}_{2}$ release by the roots. However, the overall coupled nitrification-denitrification activity corresponded to less than $30 \%$ of the average activity reported for temperate unvegetated sediments (Seitzinger \& Giblin 1996), and less than $25 \%$ of the activity reported for various unvegetated sediments in Danish fjords (Dalsgaard et al. 1998).

As indicated above, total denitrification was less than one-third of the activity expected for an equivalent unvegetated sediment. The results of the present study therefore suggest that the eelgrass vegetated sediment investigated was a poor environment for nitrifying and denitrifying bacteria, which agrees with previous data reported for Zostera noltii vegetated sediments (Rysgaard et al. 1996). This negative effect could be the result of enhanced organic loading to the sediment induced by the plants (Hemminga et al. 1991) or enhanced sedimentary $\mathrm{SO}_{4}{ }^{2-}$ reduction activity (Holmer \& Nielsen 1997, Blaaberg et al. 1998). These conditions may inhibit nitrification (Henriksen \& Kemp 1988, Sloth et al. 1995) and be beneficial for the activity of bacteria with a capacity for dissimilatory $\mathrm{NO}_{3}{ }^{-}$reduction to $\mathrm{NH}_{4}{ }^{+}$(Tiedje 1988)

\section{Nitrogen mass balance for the eelgrass bed}

Fluxes and rates of nitrogen transformations can be compiled in a mass balance for the eelgrass bed for April and August (Fig. 4). We assumed that mean rates for nitrogen transformations and fluxes could be calculated as the average of April and August rates. Given the small scale nature of this study, however, and the patchiness of the eelgrass bed, we emphasize that we might have missed important features that could alter the nitrogen budget presented in Fig. 4.

Our data showed that the eelgrass vegetated sediment was a nitrogen sink in April and August. The main flow of measured nitrogen compounds between the vegetated sediment and the water column was diverted through the plants, while the microbial pathways were insignificant. Nitrogen fixation accounted for less than $4 \%$ of the measured nitrogen input to the system, and less than $3 \%$ of the nitrogen loss from the system was due to denitrification, given that shed leaves were exported to adjacent areas. The balance between $\mathrm{NO}_{3}{ }^{-} / \mathrm{NH}_{4}{ }^{+}$fluxes, nitrogen fixation and deni- 


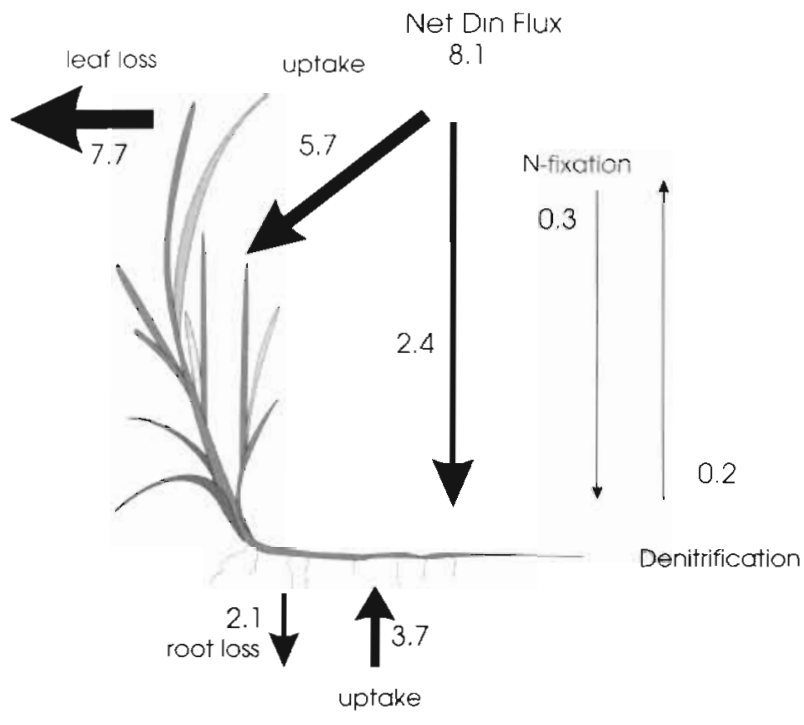

Fig. 4. Nitrogen mass balance for the eelgrass vegetated sediment for April and August. Units are mmol $\mathrm{N} \mathrm{m}^{-2} \mathrm{~d}^{-1}$

trification could explain less than $3 \%$ of the average nitrogen accumulation $\left(20.7 \mathrm{mmol} \mathrm{N} \mathrm{m} \mathrm{N}^{-2} \mathrm{~d}^{-1}\right)$ if nitrogen bound to shed leaves was exported. If the sloughed leaves, on the other hand, were retained within the bed, $-40 \%$ of the total increase in nitrogen was explained. Sedimentation of suspended matter was probably responsible for the remainder and was consequently the dominant nitrogen source for the bed.

Of the average nitrogen demand of the plants, nitrogen uptake from the pool of mineralized nitrogen in the sediment was approximately $40 \%$ of which $\mathrm{N}_{2}$ fixed by bacteria could provide less than $10 \%$. This suggests that input of particulate organic nitrogen via sedimentation (or loss of roots) followed by decomposition was of particular importance for plant growth. A tight coupling between pelagic primary production, sedimentation, mineralization and nutrient incorporation into eelgrass biomass is evident. Nitrogen initially bound in easily degradable phytoplankton can in this way be incorporated into more refractory eelgrass tissue via mineralization-assimilation processes and thus be unavailable for pelagic primary production.

Although our data indicate that the vegetated sediment was a nitrogen sink, and apparently a more significant sink than unvegetated sediment (Fig. 3), it is clear that this capacity is only temporary. Much of the inorganic nitrogen $(82 \%)$ taken up from the water column and the sediment by the plants could be returned to the environment via loss and export of leaves (Fig. 4). In principle this nitrogen could fuel new primary production. As indicated in this study, however, the turnover of nitrogen in live biomass is much slower for eelgrass than for phytoplankton. Furthermore, nitrogen bound in dead leaves is available for new primary production only after decomposition of the eelgrass tissue, and decomposition of detritus derived from Zostera marina is slow compared to decomposition of algae cells (Harrison 1989, Buchsbaum et al. 1991, Enríquez et al. 1993). An important ability of the eelgrass bed, when compared to systems dominated by ephemeral macroalgae or phytoplankton, for example, is therefore to reduce the flow and turnover of nitrogen in the autotrophic community by trapping nutrients into slowly degradable tissue during the growth season. Although the capacity for permanent nitrogen removal via denitrification is reduced when compared to unvegetated sediments, as shown in this study, it is likely that the temporal storage of nitrogen in eelgrass may imply that eelgrass beds are superior to unvegetated sediments in reducing nutrient availability during the growth season. Slow growing marine macrophytes, like eelgrass, seem better adapted to low inorganic nitrogen availability than the more fast growing plankton algae and ephemeral macroalgae (Borum 1996). The proposed ability of the plants to sequester dissolved inorganic nitrogen may therefore imply that eelgrass recolonization could accelerate estuarine restoration and thus increase ecosystem resilience.

Acknowledgements. Egon Frandsen, Marlene V. Jessen, and Sten P. Andersen are thanked for their valuable technical assistance. Four anonymous reviewers are acknowledged for their comments on this manuscript. This work was supported by the Center for Strategic Environmental Research in Marine Environments, Denmark, and is a contribution to the European Union ELOISE Programme (ELOISE No. 033) in the framework of the NICE project carried out under contract MAS3-CT96-0048.

\section{LITERATURE CITED}

Armstrong $W(1967)$ The oxidising activity of roots in waterlogged soils. Physiol Plant 20:920-926

Bach SD, Thayer GW, LaCroix MW (1986) Export of detritus from eelgrass (Zostera marina) beds near Beaufort, North Carolina, USA Mar Ecol Prog Ser 28:265-278

Blaaberg V, Mouritsen K. Finster K (1998) Diel cycles of sulphate reduction rates in sediments of a Zostera manina bed. Denmark. Aquat Microb Ecol 15:97-102

Borum J (1996) Shallow water and land/sea boundaries. In Jørgensen BB, Richardson K (eds) Eutrophication in coastal marine ecosystems. American Geophysical Union, Washington, DC, p 179-203

Borum J. Murray L, Kemp WM (1989) Aspects of nitrogen acquisition and conservation in eelgrass plants. Aquat Bot 35:289-300

Bower CE, Holm-Hansen T (1980) A salicylate-hypoclorite method for determining ammonia in seawater. Can J Fish Aquat Sc1 37:794-798

Buchsbaum R, Valiela I, Swain T, Dzierzeski M, Allen S (1991) Available and refractory nitrogen in detritus of coastal 
vascular plants and macroalgae. Mar Ecol Prog Ser 72 : $131-143$

Caffrey JM, Kemp WM (1990) Nitrogen cycling in sediments with estuarine populations of Potamogeton perfoliatus and Zostera marina. Mar Ecol Prog Ser 66:147-160

Caffrey JM, Kemp WM (1992) Influence of the submersed plant Potamogeton perfuliatus on nitrogen cycling in estuarine sediments. Limnol Oceanogr 37:1483-1495

Christensen PB, Nielsen LP, Sørensen J, Revsbech NP (1990) Denitrification in nitrate-rich streams: diumal and seasonal variation related to benthic oxygen metabolism. Limno] Oceanogr 35:640-651

Christensen PB, Revsbech NP, Sand-Jensen K (1994) Microsensor analysis of oxygen in the rhizosphere of the aquatic macrophyte Littorella uniflora (L.) Ascherson. Plant Physiol 105:847-852

Christensen PB, Sørensen J (1986) Temporal variation of denitrification activity in plant-covered littoral sediment from Lake Hampen, Denmark. Appl Environ Microbiol 51. $1174-1179$

Dalsgaard T, Rysgaard S, Christensen PB, Risgaard-Petersen $N$ (1998) Denitrification in Danish estuaries. In: Lomstein B (ed) Havmiljøet mod år 2000. Olesen og Olesen, Fredensborg (in Danish) (in press)

den Hartog C (1970) The seagrasses of the world. NorthHolland Publishing Co, Amsterdam

Duarte CM (1995) Submerged aquatic vegetation in relation to different nutrient regimes. Ophelia 41:87-112

Enríquez S, Duarte CM. Sand-Jensen K (1993) Patterns in decomposition rates among photosynthetic organisms: the importance of detritus C:N:P content. Oecologia 94: $457-471$

Flindt MR (1994) Measurements of nutrient fluxes and mass balances by on-line in situ dialysis in a Zostera marine bed culture. Verh Int Ver Limnol 25:2259-2264

Glud RN, Gundersen JK, Revsbech NP, Jørgensen BB, Huettel $M$ (1995) Calibration and performance of the stirred flux chamber from the benthic lander ELINOR. Deep-Sea Res 42:1029-1042

Grasshoff K, Erhardt M, Kremling K (1983) Methods of seawater analysis. Verlag Chemie, Weinheim

Hardy RWF, Holsten RD, Jackson EK, Burns RC (1968) The acethylene-ethylene assay for $\mathrm{N}_{2}$ fixation: laboratory and field evaluation. Plant Physiol 43:1158-1207

Harrison PG (1989) Detrital processing in seagrass systems: a review of factors affecting decay rates, remineralization and detritivory. Aquat Bot 23:263-288

Hemminga MA, Harrison PG, van Lent F (1991) The balance of nutrient losses and gains in seagrass meadows. Mar Ecol Prog Ser 71:85-96

Henriksen K, Kemp M (1988) Nitrification in estuarine and coastal manine sediments. In: Blackburn TH, Sørensen J (eds) Nitrogen cycling in coastal marine environments. SCOPE, John Wiley \& Sons Ltd, Chichester, p 201-255

Holmer M, Nielsen SL (1997) Sediment sulfur dynamics related to biomass-density in Zostera marina (eelgrass) beds. Mar Ecol Prog Ser 146:163-171

Kenworthy WJ, Zieman JC, Thayer GW (1982) Evidence for the influence of seagrasses on the benthic nitrogen cycle in a coastal plain estuary near Beaufort, North Carolina (USA). Oecologia 54:152-158

Lomstein BAa, Jensen AGU, Berntsen J, Hansen LS, Rønbøg IS, Finster KW (1998) Importance of bacteria for nitrogen retention in coastal marine sediments. In: Lomstein B (ed) Havmiljøet mod år 2000. Olesen og Olesen, Fredensborg (in Danish) (in press)
McGlathery KJ, Risgaard-Petersen N, Christensen PB (1998) Temporal and spatial variation in nitrogen fixation activity in the eelgrass Zostera marina rhizosphere. Mar Ecol Prog Ser 168:245-258

Moriarty DJW, O'Donohue MJ (1993) Nitrogen fixation in seagrass communities during summer in the Gulf of Carpentaria, Australia. Aust J Mar Freshwat Res 44:117-125

Nielsen LP (1992) Denitrification in sediments determined from nitrogen isotope pairing. FEMS Microbiol Ecol 86: $357-362$

Nienhuis PH, Groenendijk AM (1986) Consumption of eelgrass (Zostera marina) by birds and invertebrates: an annual budget. Mar Ecol Prog Ser 29:29-35

Nixon SW (1995) Coastal marine eutrophication: a definition, social causes and future concern. Ophelia 41:199-220

O'Donohue MJ, Moriarty DJW, MacRae IC (1991) Nitrogen fixation in sediments and the rhizosphere of the seagrass Zostera capricorni. Microb Ecol 22:53-64

Paasche E, Kristiansen $S$ (1982) Nitrogen nutrition of the phytoplankton in Oslofjord. Estuar Coast Shelf Sci 14: 237-249

Pedersen MF, Borum J (1992) Nitrogen dynamics of eelgrass Zostera marina during late summer period of high growth and low nutrient availability. Mar Ecol Prog Ser 80:65-73

Pedersen MF, Borum J (1993) An annual nitrogen budget for a seagrass Zostera marina population. Mar Ecol Prog Ser 101:169-177

Risgaard-Petersen N, Jensen K (1997) Nitrification and denitrification in the rhizosphere of the aquatic macrophyte Lobelia dortmanna (L.). Limnol Oceanogr 42:529-537

Risgaard-Petersen N, Rysgaard S (1995) Nitrate reduction in sediments and waterlogged soils measured by ${ }^{15} \mathrm{~N}$ techniques. In: Alef K, Nannipieri P (eds) Methods in applied soil microbiology. Academic Press Inc, London, p 287-296

Risgaard-Petersen N, Rysgaard S, Revsbech NP (1993) A sensitive assay for determination of ${ }^{14} \mathrm{~N} /{ }^{15} \mathrm{~N}$ isotope distribution in $\mathrm{NO}_{3}{ }^{-}$. J Microbiol Methods 17:155-164

Rysgaard S, Risgaard-Petersen N, Sloth NP (1996) Nitrification, denitrification, and nitrate ammonification in sediments of two coastal lagoons in Southern France. Hydrobiologia 329:133-144

Sand-Jensen K (1975) Biomass, net production and growth of eelgrass (Zostera marina L.) population in Vellerup Vig, Denmark. Ophelia 14:185-201

Sand-Jensen K, Prahl C, Stokholm H (1982) Oxygen release trom roots of submerged aquatic macrophytes. Oikos 38 : $349-354$

Seitzinger SP, Giblin AE (1996) Estimating denitrification in North Atlantic continental shelf sediments. Biogeochemistry $35: 235-260$

Sloth NP, Blackburn H, Hansen LS, Risgaard-Petersen N, Lomstein BAa (1995) Nitrogen cycling in sediments with different organic loading. Mar Ecol Prog Ser 116:163-170

Tiedje JM (1988) Ecology of denitrification and dissimilatory nitrate reduction to ammonium. In: Zender AJB (ed) Ecology of anaerobic microorganisms. John Wiley and Sons, Chichester, p 179-244

Welsh DT, Bourgués S, de Wit R, Auby I (1997) Effect of plant photosynthesis, carbon sources and ammonium availability on nitrogen fixation rates in the rhizosphere of Zostera noltii. Aquat Microb Ecol 12:285-290

Welsh DT, Bourgués S, de Wit R, Herbert RA (1996) Seasonal variations in rates of heterotrophic nitrogen fixation (acetylene inhibition) in Zostera noltii meadows and uncolonised sediments of the Bassin d'Arcachon, southwest France. Hydrobiologia 329:161-174

Submitted: April 28, 1998; Accepted: August 7, 1998

Proofs received from author(s): October 29, 1998 